\title{
5
}

\section{The virtual class}

\author{
J.T. Tiffin \\ The David Beattie Professor of Communications \\ Department of Communications Studies \\ Victoria University of Wellington \\ PO Box 600 \\ Wellington \\ New Zealand
}

Telephone: (04) 471-5309

Fax: (04) 495-5235

Email: John.Tiffin@vuw.ac.nz

http://www.vuw.ac.nz/comms/staffltiffin/tiffin.htm

\begin{abstract}
A long term action research programme at Victoria University of Wellington in New Zealand, has been examining the concept of the Virtual Class in terms of the educational needs of an information society and the design issues involved in its development. This paper relates the Virtual Class to Hyper Reality Technology and suggests the development of Hyper Colleges.
\end{abstract}

\section{Keywords}

Virtual Class, Information Society, Internet, Hyper Reality, Hyper College, Virtual Reality, Tele-existence, Virtual Universities

\section{INTRODUCTION}

She moved back to the quad where there was a large crowd of telepresences watching a performance of virtual music. A full moon ivoried the towers of teaching. It was the balance, she mused as she lifted off her HMD unit and savoured the heat of the midday sun. It was the special balance of the 
traditional and the new that made for a great university. That and keeping up appearances. (Tiffin and Rajasingham, 1995)

There is a magic lamp in which resides the genie of communications technology. Johannes Gutenberg gave it a rub in 1452. 'I wish' he said to the smiling genie 'there was a faster way of copying The Bible than handwriting it'. Within 30 years there was not a town in Europe that did not have its own printing press and the world was never the same again. George Stephenson found the lamp in the 1820's and wished for a way of travelling faster than a horse. Railway mania hit Europe and wherever a station was built a town joined the industrial revolution. The genie got out of the lamp after the First World War and gave the world radio, and again after the Second World War to give it television. Now someone has rubbed the lamp again and the world is about to be changed by a new communication technology. As the genie well knows, it will not be in the way that was wished for. The internet grows apace and morphs as it does so. Even an Alladin like Vernon Cerf has no idea what its final shape will be (Communications Week, 1994).

The coming of the railways marked the beginning of the industrial society. Does the development of the internet mark the break between the industrial society and the information society? The significance for us at this conference is that if this is the case then we no longer design advanced information technology tools as isolated items for an industrial society. We begin to design them as integrated components of the information technology infrastructure of an information society. Nowhere will this be more significant than in the development of IT tools for education.

\section{THE IT INFRASTRUCTURE OF AN INFORMATION SOCIETY}

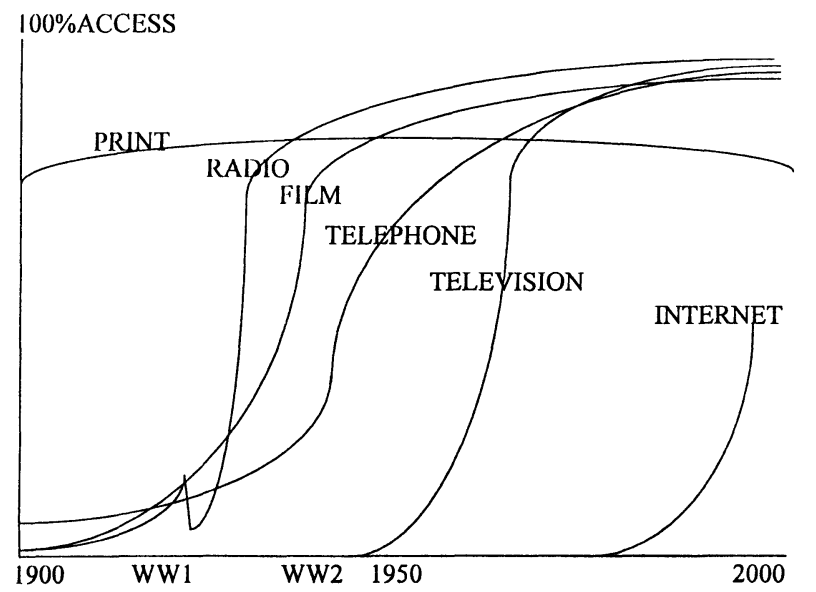

Figure 1 The growth of virtual reality technologies in industrial societies in the 20th century 
Apart from the telephone, the technologies in Figure 1 are normally conceptualised as mass media and seen as having a profound effect on industrial societies. What all these technologies have in common is the ability to evoke the effect of a reality that does not in physical fact exist. It is in this sense that they are termed virtual reality technologies and seen as precursors to computer generated virtual reality. What Figure 1 shows is that as the century draws to a close most people in industrial countries can access the early virtual reality technologies of print, radio, television, film, and the telephone. By contrast, apart from the telephone and print, nobody would have had access to these technologies at the beginning of the century.

The exponential growth of the internet at the moment suggests that it is yet another virtual reality technology in a stage of rapid adoption. Yet there is something more. Like the computer, the internet is rapidly changing its nature as it grows. If it does not become chaotic, if it acquires the bandwidth and processing capability that Negroponte (1995) envisages for a global information infrastructure then it could not only subsume the primitive virtual reality technologies but it could also be a vehicle for distributing computer generated threedimensional audio, video and haptic interactive immersive virtual reality.

There are only so many hours in the day to dedicate to the different media that we use for information. As Innis (1950) and McLuhan (1964) pointed out the ratio in which we expose ourselves to different media profoundly modifies the way we live and the society we live in. People today in developed countries spend far more of their time in some kind of virtual reality than people did at the beginning of this century and this indicates the direction the information society is taking. It is acquiring an infrastructure like that of roads, electricity and water pipes that allows the co-existence and interaction of virtual reality and physical reality.

As President of ATR Communication Systems Laboratories Dr Nobuyoshi Terashima led a team that demonstrated the feasibility of a seamless intermixing of physical and virtual reality and termed the technology 'Hyper Reality'. Dr Terashima and I are co-editing a book on Hyper Reality in which a number of distinguished authorities have attempted to conceptualise how such an infrastructure could impact on such areas as medicine, government and transport. My interest is in the design of an educational system. How will people be prepared for a society in which the doctor one is consulting, the dog one is patting or the plant that is growing in the corner of the room, may be made of bits or may be made of atoms and it becomes increasingly difficult to determine the difference?

A kind of Hyper Reality has always existed in the classroom. The words of a good teacher or a textbook evoke images in the mind. Educational video and radio have the power to make the classroom walls disappear to be replaced by mental images. Are we witnessing the evolution of the conventional classroom into a Hyper Reality classroom or does the development of the internet presage something more revolutionary? 


\section{VIRTUAL EDUCATION ON THE INTERNET}

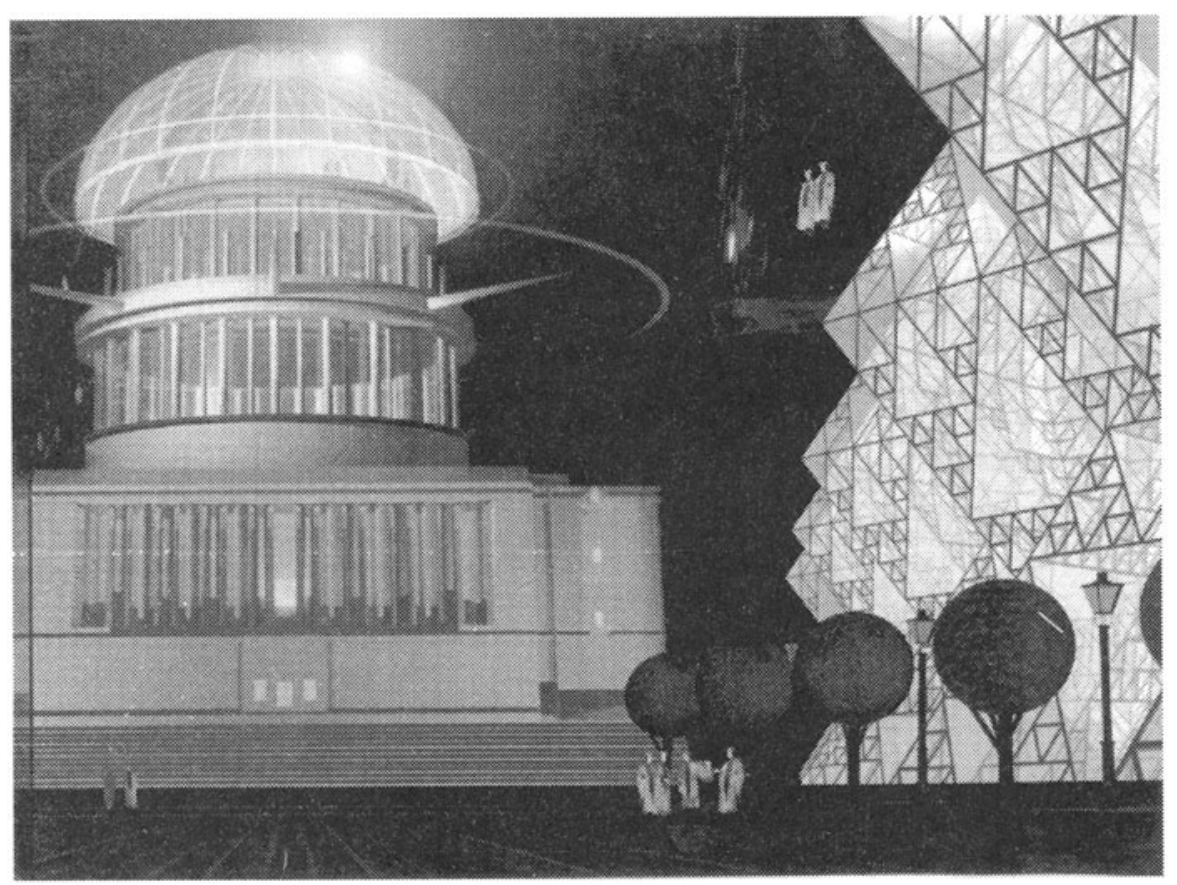

Figure 2 The University of Tele-Existence (reproduced from Tiffin, J. and Rajasingham, L. (1995). In Search of the Virtual Class: Education in an Information Society. Routledge, London and New York.)

Figure 2 is a design for a university in VRML on the internet. The idea is simply that as with such systems as WorldChat a person on the internet can embody themselves as an avatar and locate themselves in the quadrangle of a virtual university where they can go to a virtual library, a virtual classroom, a virtual research centre or a virtual student union. It is in effect a kind of three dimensional educational browser which allows a person to find their way into different educational virtual realities.

Such scenarios may well become common on the internet and give embodiment to the virtual universities, colleges and schools that are beginning to proliferate there. This is a direction education will inevitably take as long as the internet continues to develop as the infrastructure of an information society. However, although it may suffice for many autonomous learners and 
for those who find it difficult to attend a real class, I suspect the development of such on-line virtual education will in the main be in conjunction with conventional classes. After ten years of research in this field, what impresses me most is the importance of the socialising function in education. Students want to meet with students, real students as well as virtual ones. We may in the future spend more of our time with virtual reality but the effect may well be to make us value physical reality more. We need to find a balance between physical and virtual reality both in education and in the information society it prepares people for.

\section{EDUCATION IN HYPER REALITY}

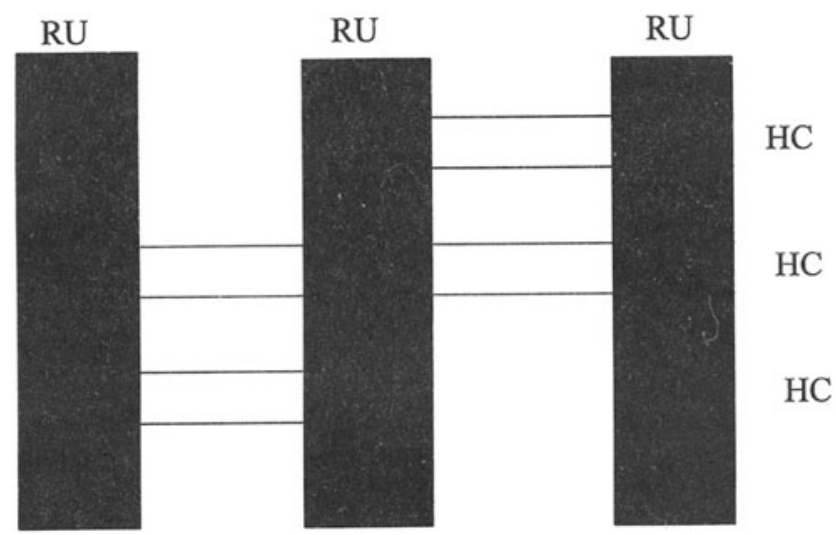

Figure 3 The Hyper College

Figure 3 looks at the case of three universities which exist because they are made of atoms. These universities are real and have a hinterland that supports their existence. Students drawn from that hinterland come to these universities because of the variety of subjects they offer and because they have an attractive social life. Students in real universities do a wide variety of courses in the language that they understand and in terms of the territory they know.

The three universities have subjects in common. It stands to reason that gains could be made in efficiency and in the richness of the teaching and research if similar subject departments in the different universities could be combined in a virtual college specialising in one particular subject. This is the idea for a Hyper College, a place that combines education in real and virtual environments.

The Network College of Communications in the Pacific (NCCP) is an early example of an attempt to do this. Departments of communication studies in Pacific rim universities and research institutes interested in communication, especially as it involves information technology have created a loose structure that promotes co-operation on the internet. It 
recognises the importance of teaching and research that seeks to be global rather than local in nature. Students want qualifications that are valid in other countries besides their own. Members have run joint courses using the internet, and audiographic and video conferencing. Academic members turn up as telepresences in each other's classes to give seminar papers.

At the Department of Communication Studies at Victoria University an action research programme to develop a virtual class has been in place for the last 10 years (Tiffin, 1996). The research is based on the assumption that whatever the internet becomes will gradually acquire the bandwidth that is needed for the kind of technology Dr Terashima developed at ATR Communication Systems Laboratory and that it will be possible to adapt it to education. This opens the possibility for a Hyper College an idea that is being jointly explored by Dr Terashima, Professor Saga of Asia University, Dr Rajasingham of Victoria University of Wellington and myself. It would have a database of virtual objects, settings and people that related to the subject domain. In this way it would be possible to create what Dr Terashima calls co-action environments whereby teachers and students in the different classrooms in the different universities that comprised the hyper college could interact with each other as real and virtual people studying together real and virtual embodiments of their subject matter.

It becomes possible that knowledge and the teaching of it could increasingly grow to reside in simulacra as distinct from text, matched against reality rather than being based on bibliography, taught by artificial intelligences as well as human teachers and available any where any time to learners learning to live locally and globally with realities that are part derived from atoms and part from bits of information.

\section{REFERENCES}

Communications Week, 21 February 1994, p. 29.

Innis, H. A. (1950) Empire of Communications. University of Toronto Press, Toronto. McLuhan, M. (1964). Understanding Media. McGraw Hill, New York.

Negroponte, N. (1995) Being Digital. Hodder \& Sloughton, Australia and New Zealand.

Tiffin, J. and Rajasingham, L. (1995), In Search of the Virtual Class: Education in an Information Society. Routledge, London and New York.

John Tiffin (1996). The Virtual Class is Coming. (Forthcoming in Vol 1, Issue 1, Education and Information Technologies) 


\section{BIOGRAPHY}

John Tiffin is a communications specialist in the design and evaluation of instructional system. He has a particular concern for the applications of new information technologies to learning.

As a consultant, John Tiffin has served the governments of New Zealand, Britain, Brazil and Ethiopia, the Organisation of American States, the World Bank, the International Telecommunications Union, the Academy for Educational Developments, the Centre for Educational Developments Overseas, and UNESCO. He has been a school director, a television producer and a researcher and is the co-founder of the Network College of Communications in the Pacific (NCCP).

John Tiffin is a citizen of New Zealand and the United Kingdom. He is a graduate of the University of Leeds, and has a Masters from Liverpool University and a $\mathrm{PhD}$ from Florida State University. He holds the David Beattie Chair of Communications at Victoria University of Wellington, New Zealand. 